() Н. В. Менжинська, канд. техн. наук, Українська академія друкарства, Львів, Україна

\title{
ЗАБЕЗПЕЧЕННЯ КОМФОРТНИХ УМОВ ПРАЦІ ПРИ РОБОТІ З ВІЗУАЛЬНИМИ ДИСПЛЕЙНИМИ ТЕРМІНАЛАМИ ПЕРСОНАЛЬНИХ КОМП’ЮТЕРІВ
}

У статті, на основі інформаційного пошуку у літературних та електронних джерелах, проаналізовано питання 3 охорони та безпеки праці осіб, робота котрих безпосередньо пов'язана з використанням персональних комп'ютерів.

Розглянуто причинно-наслідкові зв'язки роботи за візуальними дисплейними терміналами персональних комп'ютерів та захворюваннями, які виникають у процесі роботи на них. Наведено оптимальні показники метеорологічних умов мікроклімату для категорій Іа та Іб (відносна вологість повітря, температура та швидкість руху повітря) у робочій зоні виробничого приміщення, які забезпечуватимуть комфортні умови праці. Вказано

чинники впливу на рівень працездатності та самопочуття осіб, згідно санітарних норм, наведено їхні характеристики та вимоги до них.

Ключові слова: персональний комп'ютер; екран монітора; безпека праці; охорона праці; санітарні норми.

\section{Постановка проблеми}

Сучасний етап технологічного розвитку характеризується розробкою та пошуком новітніх методів обробки інформації. На сьогодні персональні комп'ютери щільно увійшли в життя суспільства та є основним або допоміжним інструментом у роботі. Зручність у використанні комп'ютерів очевидна: всі дані зберігаються в цифровому форматі, що не вимагає накопичення великої кількості паперових носіїв, вирішення задачі обробки даних здійснюється порухом електронної миші чи зручним введенням за допомогою клавіатури, без зайвих зусиль. Зазвичай, прогресивні нововведення та вдосконалення вже існуючих технологічних надбань спрощують та покращують роботу та життя людини [1, 2]. Завдяки зручності у користуванні персональними комп'ютерами, питання їх шкідливого впливу на окремі органи людини чи здоров'я в цілому не було актуальним певний період часу. Позаяк, тривала та посилена робота за комп'ютером може стати причиною погіршення здоров'я та призвести до появи

(c) $2019 \mathrm{p}$. 


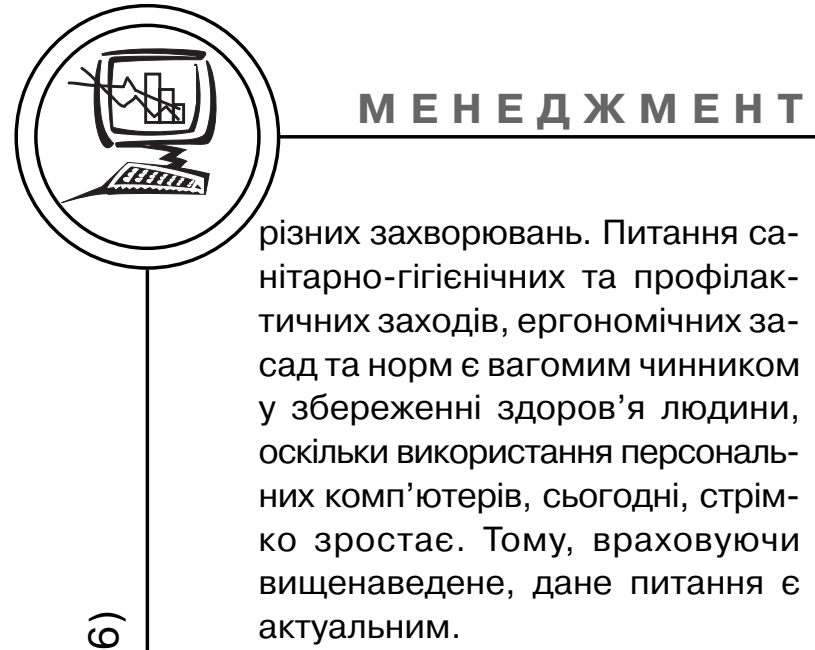

\section{Мета роботи}

Виокремити та проаналізувати основні чинники впливу на здоров'я осіб, які працюють за моніторами персональних комп'ютерів.

\section{Аналіз попередніх досліджень}

Монітор - екранний пристрій, без якого неможливо здійснювати операції, пов'язані з введенням та обробкою інформаційних даних. Від вірного вибору монітора багато в чому залежить стан зорового апарату людини, якість виконання роботи, рівень продуктивності праці тощо. Відомо, що особи, професійна діяльність яких пов'язана 3 довготривалим використанням персональних комп'ютерів частіше мають погіршення загального стану здоров'я: зниження функціональності опорнорухового та зорового апарату, порушення в роботі центральної нервової, інших систем та органів людського організму [3-6].

\section{Результати проведених досліджень}

Низький показник контрастності візуальних дисплейних терміналів та особливість цифрового комп'ютерного зображення (мерехтіння, піксельна будова) втом- лює очі користувача та є причиною багатьоххвороб зорового апарату. В одному з розділів Директиви 90/270/ЄEC - про мінімальні вимоги безпеки та здоров'я при роботі з екранними пристроями чітко прописано позиції щодо використання ВДТ, зокрема: цифрове зображення повинно бути стабільним; усі символи цифрового зображення повинні бути чіткими, з певною відстанню та розмірами; можливість швидкого регулювання контрасту та яскравості зображення; екран монітора не повинен мати ефекту відбивання світла; можливість різнобічного регулювання положення монітора для зручності користувача ПК. Computer vision syndrome (англ.) - CVS або комп'ютерний зоровий синдром (КЗС), сьогодні можна вважати одним 3 самих розповсюджених порушень зору у людей, які працюють за комп'ютером [7]. Дослідження показують, що симптоматика КЗС, а саме: погіршення зорового сприйняття, зоровий ефект МакКалаха (при переведенні погляду з монітора на білий чи чорний предмет, останній «забарвлюється» в колір, який був домінуючим на зображенні екрану), подвоєння об'єктів виникає у 40 \% людей, безпосередньо працюючих за моніторами. Очний дискомфорт, сухість в очах, відчуття печіння, неадекватне реагування на кондиціоноване повітря, дим тощо, це прояви синдрому «сухого ока», який в подальшому призводить до погіршення зору з порушенням стабільності сльозової плівки та ймовірним пошкодженням слизової ока. Даний синдром викликаний зниженням кількості мигальних рухів очей, що є притаманним 
для працюючих за візуальними дисплейними терміналами персональних комп'ютерів (ВДТ ПК). 3 огляду на те, що погляд людини, наприклад, оператора ПК, з різною періодичністю зосереджується на різних об'єктах: монітор-клавіатура-аркуш паперу тощо, навантаження на зоровий апарат збільшується. Відомо, що за рахунок зміни форми (кривизни) кришталика здорове око може пристосовуватись до бачення та розрізнення предметів на неоднаковій відстані, називається акомодацією. При довготривалій роботі на близькій відстані, зокрема за ВДТ, виникає спазм акомодації i, як наслідок - порушення чіткості сприйняття об'єктів [8]. Для зниження навантаження на очі користувача комп'ютера можна застосовувати різноманітні захисні елементи наприклад, та антиблікові фільтри.

Доведено, що монітори виділяють наступні види випромінювань: інфрачервоне рентгенівське, електромагнітне, ультрафіолетове. Стабільно-тривалий вплив іонізуючого випромінювання (IB) на організм може, з часом викликати біологічні зміни та мати незворотну дію та спричинити втрату працездатності, порушення обміну речовин та функціональних розладів кровотворних органів, погіршення самопочуття, можливі зміни у складі крові [9]. Окрім того, незначні дози випромінювань мають здатність накопичуватись в організмі людини, це так званий «кумулятивний ефект». Тому, для проведення генерації негативних іонів в приміщені необхідно застосовувати спеціалізовані прилади та механізми. У даному випадку - це прилади для зволоження повітря та іонізатори, а також кондиціонери, які передбачають налаштування вологості, швидкості руху та температури повітря, його дезінфекції. Такі пристрої не повинні створювати дискомфорту під час експлуатації.

Системи для кондиціонування й вентиляції повітря та опалення повинні бути встановлені згідно норм ДБН В.2.5-67:2013 Опалення, вентиляція та кондиціонування (затверджених наказом Мінрегіону від 25.01.2013 р. № 24.). Відповідно до ДБН В.2.5-28-2006 Інженерне обладнання будинків і споруд. Природне і штучне освітлення, Санітарних норм мікроклімату виробничих приміщень ДСН 3.3.6.042-99, Державних санітарних правил і норм роботи 3 візуальними дисплейними терміналами електронно-обчислювальних машин ДСанПІН 3.3. 2.007-98, НПАОП 0.00-7.15-18 Вимоги щодо безпеки та захисту здоров'я працівників під час роботи з екранними пристроями у таблиці наведено норми щодо освітлення, оптимальних умов мікроклімату та інших показників, які мають безпосередній вплив на самопочуття та здоров'я людини, яка використовує для своєї роботи монітор ПК.

Для підтримування працездатності на належному рівні, а також унеможливлення виникнення професійних захворювань необхідно дотримуватись регламентованих годин щодо перерв для фізичного й психоемоційного відпочинку та особистих потреб працюючих відповідно до трудових норм. Зважаючи на вид трудової діяльності та важкості виконуваної 


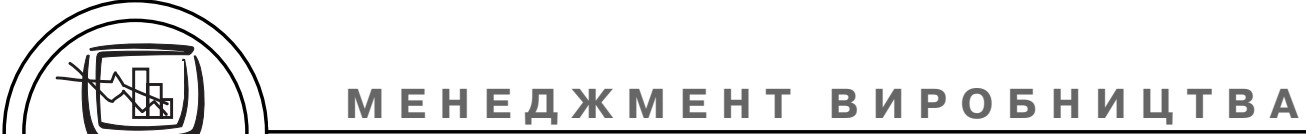

\begin{tabular}{|c|c|}
\hline \multicolumn{2}{|c|}{ Основні ергономічні вимоги } \\
\hline Показник & Вимоги та рекомендації \\
\hline Природне освітлення & $\begin{array}{l}\text { Віконні отвори, розташовані у керунку на північний } \\
\text { схід чи на північ. КПО - не нижче, ніж 1,5 \% }\end{array}$ \\
\hline $\begin{array}{l}\text { Загальне рівномірне } \\
\text { освітлення }\end{array}$ & $\begin{array}{l}\text { Світильники з використанням розсіювачів та дзер- } \\
\text { кальних екранних сіток або віддзеркалювачами з ви- } \\
\text { сокочастотними пускорегулювальними апаратами. } \\
\text { Показник дискомфорту - не більше } 15 . \text { Коефіцієнт } \\
\text { пульсації не повинен перевищувати } 10 \text { \%. } \\
\text { Яскравість стелі, у випадку застосування системи } \\
\text { відбитого освітлення - } 200 \text { кд/м². }\end{array}$ \\
\hline $\begin{array}{l}\text { Освітленість робочої } \\
\text { поверхні }\end{array}$ & $\begin{array}{l}\text { При загальному освітленні: 200, } 400 \text { лк; } \\
\text { при комбінованому освітленні: 500/300 лк. }\end{array}$ \\
\hline Місцеве освітлення & $\begin{array}{l}\text { Світильники з півпрозорим відбивачем світла із за- } \\
\text { хисним кутом не меншим, ніж } 40^{\circ} \text {. }\end{array}$ \\
\hline Параметри мікроклімату & $\begin{array}{l}\text { Для категорії робіт 1а: температура повітря: холод- } \\
\text { ний період року }-22-24^{\circ} \text { С; теплий період року - } \\
23-25^{\circ} \text { С. } \\
\text { Відносна вологість повітря: холодний період року - } \\
75 \text { \%; теплий період року }-40-60 \% \text {. } \\
\text { Швидкість руху повітря: холодний та теплий періоди } \\
\text { року - 0,1 м/с. } \\
\text { Для категорії робіт 1б: температура повітря: } \\
\text { холодний період року }-21-23^{\circ} \text { С; теплий період } \\
\text { року - } 22-24^{\circ} \text { С. } \\
\text { Відносна вологість повітря: холодний та теплий пе- } \\
\text { ріоди року - 40-60 \%. } \\
\text { Швидкість руху повітря: холодний період року - 0,1 } \\
\text { м/с; теплий період року - 0,2 м/с. } \\
\text { Вміст пилу - не більше } 4 \text { мг/м³. }\end{array}$ \\
\hline $\begin{array}{l}\text { Рівень іонізації повітря в } \\
\text { приміщенні }\end{array}$ & $\begin{array}{l}\text { Оптимальний - } 1500-3000 \text { іонів в } 1 \text { см³ повітря; } \\
\text { макс. допустимий }-3000-5000 \text { іонів в } 1 \text { см}^{3} \text { по- } \\
\text { вітря. }\end{array}$ \\
\hline $\begin{array}{l}\text { Напруженість електричного } \\
\text { поля ВДТ }\end{array}$ & $20 \mathrm{kB} / \mathrm{M}$ \\
\hline $\begin{array}{l}\text { Вимоги до розташування } \\
\text { монітора }\end{array}$ & $\begin{array}{l}\text { Нижче рівня очей приблизно на } 15^{\circ} \text {. Можливість ре- } \\
\text { гулювання екрану в лівому та правому керунку, за } \\
\text { вертикальним нахилом та висотою згідно індиві- } \\
\text { дуальних потреб користувача ПК. } \\
\text { Відстань монітора до очей: } 60-70 \text { см. }\end{array}$ \\
\hline Короткотривалі перерви & $\begin{array}{l}\text { Тривалістю 10-15 хв. } 1 \text { раз на 1-2 год. залежно від } \\
\text { складності виконуваної роботи. }\end{array}$ \\
\hline Екран монітора & $\begin{array}{l}\text { Яскравість відблисків на поверхні екрану: не більше } \\
40 \text { кд/м²; } \\
\text { розмір точки свічення (мін.): монохромний монітор - } \\
\text { не більше 0,4 мм, кольоровий монітор - не менше } \\
\text { 0,6 мм. }\end{array}$ \\
\hline Робоча поверхня & $\begin{array}{l}\text { З низькою відбиваючою здатністю та достатніми } \\
\text { (відповідними) розмірами. }\end{array}$ \\
\hline
\end{tabular}


Закінчення табл.

\begin{tabular}{|c|c|}
\hline Показник & Вимоги та рекомендації \\
\hline Висота стільця & 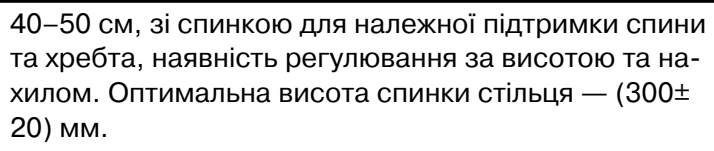 \\
\hline $\begin{array}{l}\text { Висота робочої поверхні } \\
\text { столу }\end{array}$ & $68-80 \mathrm{~cm}$. \\
\hline Кольори інтер'єру & $\begin{array}{l}\text { Матова чи півматова фактура поверхні, середньої } \\
\text { світлості, } \rho-0,3-0,6 \text {. }\end{array}$ \\
\hline
\end{tabular}

роботи, для працюючих з ВДТ розроблено режими праці і відпочинку. Також, не слід забувати про необхідність виконання профілактичних вправ для зорового апарату [10]. Значні психо-емоційні навантаження, низька та обмежена рухова активність сприяють погіршенню функцій центральної нервової системи, а звідси зниженню продуктивності праці. Тому роботодавець зобов'язаний забезпечити відведення спеціальних приміщень для фізичного та психологічного розвантаження та передбачених перерв. Періодичні медичні обстеження, котрі мають бути невід'ємним та періодичним заходом, дозволять виявити погіршення здоров'я й контролювати вже набуті порушення в роботі систем та органів осіб, що виникли внаслідок професійної діяльності [11].

Раціональна організація робочого місця є важливим фактором, котрий має значний вплив на зоровий апарат, втомлюваність та рівень працездатності людини, яка працює з ВДТ. Облаштування та оснащення робочого місця повинно проводитись відповідно до антропометричних та психологічних особливостей та вимог особи. За потреби, на робочому місці, можна використовувати підставку для ніг (кут нахилу опорної поверхні - до 20 ). В осіб, які тривалий час працюють за комп'ютером часто діагностують тунельний синдром або синдром зап'ястного каналу, який виникає внаслідок стискування серединного нерва в зап'ястковому каналі. Щоб уникнути, порушень в опорно-руховому апараті та м'язовій системі необхідно періодично виконувати профілактичні вправи та звернути увагу на правильність положення тіла при роботі за ВДТ ПК та коректно підібирати меблі (стіл та стілець) [12].

Перед початком роботи за ВДТ ПК працівник зобов'язаний пройти вступний та первинний інструктаж з охорони праці. Згодом, передбачено проведення інструктажів один раз на шість місяців. Важливо, до роботи з ПК можуть бути допущені лише ті особи, котрі пройшли медичний огляд та не мають жодних медичних протипоказань щодо проведення роботи за ВДТ ПК [8]. Виконання вимог щодо ергономічності та безпеки праці працівників покладено на роботодавця, який несе відповідальність за неналежне облаштування робо- 


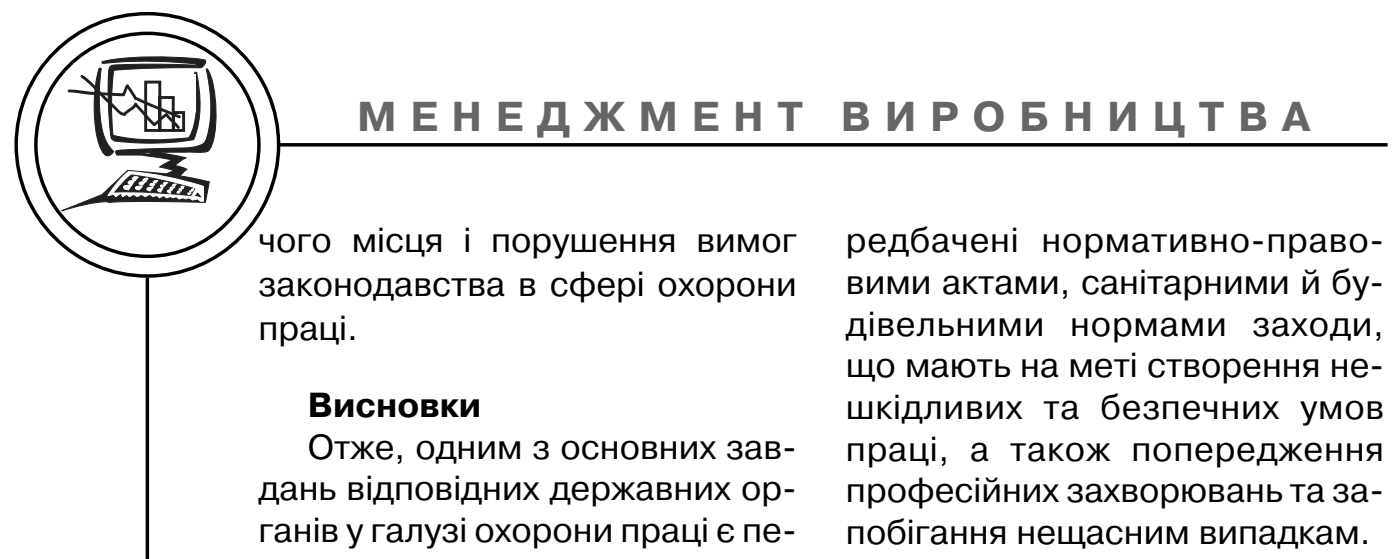

\section{Список використаної літератури}

1. Старушенко Г. А. Статистична обробка даних в системі публічного управління: Навч. посіб. / Г. А. Старушенко. Дніпро: ГРАНІ, 2018. 144 с.

2. Євдокимов В. В. Особливості впровадження комп'ютерних систем бухгалтерського обліку на великих підприємствах / В. В. Євдокимов // Проблеми теорії та методології бухгалтерського обліку, контролю і аналізу. 2009. № 1(13). C. 193-202. DOI: https://pbo.ztu.edu.ua/article/view/62210.

3. Жидецький В. Ц. Охорона праці користувачів комп'ютерів: Навч. посіб. 2-ге вид., доп. / В. Ц. Жидецький. Л.: Афіша, 2001. 176 с.

4. Шевчук Л. Т. Соціально-економічні аспекти впливу новітніх технологій на індивідуальне та суспільне здоров'я / Л. Т. Шевчук, Л. М. Федоришина // Сталий розвиток економіки. 2014. № 3(25). C. 17-22. DOl: https://www.irbisnbuv.gov.ua/cgi-bin/irbis_nbuv/cgiirbis_64.

5. Як впливає комп'ютер на наше здоров'я. [Електронний ресурс]. Режим доступу: https://www.epochtimes.com.ua/articles/view/8/13908.html.

6. Варавін А. М. Вплив комп'ютера на здоров'я людини / А. М. Варавін, О. В. Рибалка, Н. І. Ушакова // Вісник Харківського національного університету ім. В. Н. Каразіна. Серія «Валеологія: сучасність і майбутнє». 2017. № 21. C. 34-37. DOI: http://periodicals.karazin.ua/valeology/article/view/8519.

7. Кашкаров А. Комп'ютерний зоровий синдром. [Електронний ресурс]. Режим доступу: https://www.dut.edu.ua/ua/news-1-597-729-komp.

8. Корженевський О. С., Чернушак І. І. Професійні захворювання програмістів та їх профілактика. [Електронний ресурс]. Режим доступу: https://confopcb.iee.kpi.ua/confopcb.iee.kpi.ua.

9. Жидецький В. Ц. Основи охорони праці: Навч. посіб. / В. Ц. Жидецький. Київ: Знання, 2010. 376 с.

10. Стасюк О. М. Лікувальна фізична культура в офтальмології: консп. лекц. [Електронний ресурс]. Режим доступу: https://repository.ldufk.edu.ua/ handle/34606048/15323.

11. Закон України «Про охорону праці» від 14 жовтня 1992 р. № 2694-XII. URL: https://zakon.rada.gov.ua/laws/show/2694-12.

12. Желібо Є. П. Безпека життєдіяльності: Навч. посіб. 3-є вид. / Є. П. Желібо, Н. М. Заверуха, В. В. Зацарний. Київ: Каравела, 2004. 328 с.

\section{References}

1. Starushenko, H. A. (2018). Statystychna obrobka danykh v systemi publichnoho upravlinnia. Dnipro: HRANI, 144 p. [in Ukrainian].

2. Yevdokymov, V. V. (2009). Osoblyvosti vprovadzhennia komp'iuternykh system bukhhalterskoho obliku na velykykh pidpryiemstvakh. Journal of Problemy teorii ta metodolohii bukhhalterskoho obliku, kontroliu i analizu, 1(13), 193-202. DOI: https://pbo.ztu.edu.ua/article/view/62210 [in Ukrainian]. 
3. Zhydetskyi, V. Ts. (2001). Okhorona pratsi korystuvachiv komp'iuteriv. Lviv: Afisha, 176 p. [in Ukrainian].

4. Shevchuk, L. T. \& Fedoryshyna, L. M. (2014). Sotsialno-ekonomichni aspekty vplyvu novitnikh tekhnolohii na indyvidualne ta suspilne zdorov'ia. Journal of Stalyi rozvytok ekonomiky, 3(25), 17-22. DOI: https://www.irbisnbuv.gov.ua/cgi-bin/irbis_nbuv/cgiirbis_64 [in Ukrainian].

5. Yak vplyvaie kompiuter na nashe zdorov'ia. Retrieved from https://www. epochtimes.com.ua/articles/view/8/13908.html [in Ukrainian].

6. Varavin, A. M. \& Rybalka, O. V. \& Ushakova, N. I. (2017). Vplyv komp'iutera na zdorov'ia liudyny. Journal of Visnyk Kharkivskoho natsionalnoho universytetu im. V. N. Karazina. Seriia 'Valeolohiia: suchasnist i maibutnie', 21, 34-37. DOI: http://periodicals.karazin.ua/valeology/article/view/8519 [in Ukrainian].

7. Kashkarov, A. Komp'iuternyi zorovyi syndrom. Retrieved from https:// www.dut.edu.ua/ua/news-1-597-729-komp [in Ukrainian].

8. Korzhenevskyi, O. S. \& Chernushak, I. I. Profesiini zakhvoriuvannia prohramistiv ta yikh profilaktyka. Retrieved from https://confopcb.iee.kpi.ua/confopcb.iee.kpi.ua [in Ukrainian].

9. Zhydetskyi, V. Ts. (2010). Osnovy okhorony pratsi. Kyiv: Znannia, 376 p. [in Ukrainian].

10. Stasiuk, O. M. Likuvalna fizychna kultura $v$ oftalmolohii. Retrieved from https://repository.Idufk.edu.ua/handle/34606048/15323 [in Ukrainian].

11. Zakon Ukrainy 'Pro okhoronu pratsi' vid 14 zhovtnia 1992 r. № 2694-XII. Retrieved from https://zakon.rada.gov.ua/laws/show/2694-12 [in Ukrainian].

12. Zhelibo, Ye. P. \& Zaverukha, N. M. \& Zatsarnyi, V. V. (2004). Bezpeka zhyttiediialnosti. Kyiv: Karavela, 328 p. [in Ukrainian].

В статье на основе информационного поиска в литературных и электронных источниках проанализированы вопросы по охране и безопасности труда лиц, работа которых непосредственно связана с использованием персональных компьютеров. Рассмотрены причинно-следственные связи работы с визуальным дисплейными терминалами персональных компьютеров и заболеваниями, которые возникают в процессе работы на них. Приведены оптимальные показатели метеорологических условий микроклимата для категорий Іа и Іб (относительная влажность воздуха, температура и скорость движения воздуха) в рабочей зоне производственного помещения, которые обеспечивают комфортные условия труда.

Перечислены также важные факторы влияния на уровень работоспособности и самочувствия лиц, согласно санитарных норм, приведены их характеристики и требования к ним.

Ключевые слова: персональный компьютер; экран монитора; безопасность труда; охрана труда; санитарные нормы. 
Based on an informative searchin literary and electronic sources, analyzes and addresses the issues of occupational safety and health of persons directly involved in the use of personal computers. The causes and effects of work on the visual display terminals of personal computers and the diseases that occur during the work on the mare considered. The optimum indicators of the meteorological conditions of the microclimate for the categories la and Ib (relative humidity, temperature and air velocity) in the working area of the production premises are provided, which will provide comfortable working conditions. The list of important factors influencing the level of working capacity and well-being of persons, according to sanitary norms, describes their characteristics and requirements for them.

Keywords: personal computer; monitor screen; safety of work; guard of work; health standards.

\author{
Рецензент - О. І. Бараускєне, канд. техн. наук, \\ доц., КПІ ім. Ігоря Сікорського
}

Надійшла до редакції 21.12.19 